\title{
TINGGI BADAN REMAJA DI DAERAH ENDEMIS GONDOK DI NGARGOYOSO KARANGANYAR: A CROSS SECTIONAL STUDY
}

\author{
$\underline{\text { Siti Munawaroh }}^{1^{*}}$, Asadullah Fathy Muhammad ${ }^{2}$, Selfi Handayani ${ }^{1}$ \\ 1. Departemen Anatomi Fakultas Kedokteran Universitas Sebelas Maret, Surakarta, Indonesia \\ 2. Program Studi Kedokteran Fakultas Kedokteran Universitas Sebelas Maret, Surakarta, \\ Indonesia \\ E-mail: munafkuns@staff.uns.ac.id
}

\begin{abstract}
ABSTRAK
Pendahuluan: Asupan yodium yang kurang dapat menimbulkan berbagai gejala termasuk gondok atau pembesaran kelenjar tiroid yang disebut juga Gangguan Akibat Kekurangan Yodium (GAKY). Yodium diperlukan untuk membentuk hormon tiroid yang mengatur pertumbuhan dan perkembangan tubuh manusia. Tidak terpenuhinya kebutuhan yodium dapat menyebabkan hipotiroidisme, penyerapan kalsium terhambat, gangguan metabolisme karbohidrat dan protein, dan gangguan pertumbuhan, seperti tinggi badan. Penelitian ini bertujuan untuk menganalisis perbedaan tinggi badan antara remaja di daerah endemis gondok dan daerah non endemik gondok di Karanganyar. Metode: Penelitian cross sectional yang dilakukan di Karanganyar yang terbagi menjadi dua, yaitu di Ngargoyoso sebagai daerah endemis gondok dan di Colomadu sebagai daerah bebas gondok. Sampel penelitian adalah remaja fase akhir, yaitu siswa SMK kelas XII. Pengambilan sampel dilakukan dengan teknik simple random sampling dan diperoleh 187 responden. Data diperoleh dari pengukuran tinggi badan remaja kemudian dianalisis secara menggunakan uji $t$ independen. Hasil: Rerata tinggi badan pada kelompok remaja daerah endemis gondok $(N=84)$ adalah 162,29 dan remaja di daerah bebas gondok $(N=103)$ adalah 167,01. Hasil analisis uji t-independen terhadap tinggi badan kedua kelompok menunjukkan adanya perbedaan yang signifikan $(p=0,001)$. Kesimpulan: Tinggi badan remaja di daerah endemis gondok di kecamatan Ngargoyoso Kabupaten Karanganyer lebih rendah dibandingkan remaja di daerah non-endemis gondok
\end{abstract}

Kata kunci: GAKY, endemis gondok, tinggi badan

\begin{abstract}
Introduction: Insufficient iodine intake can cause various symptoms, including a goitre or enlargement of the thyroid gland, also known as Iodine Deficiency Disorder (GAKY). Iodine is needed to form thyroid hormones that regulate the growth and development of the human body. Unmet need for iodine can cause hypothyroidism, inhibited calcium absorption, impaired carbohydrate and protein metabolism, and impaired growth, such as height. This study aims to analyze the difference in height between adolescents in endemic goitre areas and non-endemic areas of goitre in Karanganyar. Methods: This cross-sectional study was conducted in Karanganyar, divided into two, namely in Ngargoyoso as an endemic goitre area and in Colomadu as a goitre-free area. The research sample is the final phase of youth, namely students of SMK class XII. Sampling was done by simple random sampling technique and obtained 187 respondents. Data were obtained from the measurement of adolescent height and then analyzed using an independent $t$ test. Results: The mean height of adolescents in endemic goitre areas $(N=84)$ was 162.29 , and adolescents in the goitre-free area $(N=103)$ was 167.01. The results of the independent t-test analysis on the height of the two groups showed a significant difference $(p=0.001)$. Conclusion: The height of adolescents in endemic goitre areas is lower than adolescents in non-endemic areas of goitre
\end{abstract}

Keywords: Iodine Deficiency, endemic goiter, height 


\section{PENDAHULUAN}

Remaja adalah periode transisi manusia dari anakanak menuju dewasa. Pada periode ini, manusia mengalami masa pubertas dan mengalami beberapa perubahan, diantaranya mengalami pertumbuhan fisik yang dramatis, perkembangan seks sekunder serta perkembangan organ-organ reproduksi. $(1,2)$

Pertambahan tinggi badan yang cepat pada remaja perempuan umumnya dimulai sejak usia 9,5 sampai 14,5 tahun, yaitu selama Sexual Maturity Rating (SMR) stage 2, dan akan berhenti pada umur 16,5 tahun dengan ratarata pertambahan tinggi badan sekitar $8-9 \mathrm{~cm}$ per tahun. Sedangkan remaja laki-laki umumnya mengalami pertambahan tinggi badan pada usia antara 10,5 -16 tahun atau 13-17,5 tahun dengan rata-rata pertambahan tinggi badan sekitar 7-12 cm per tahun dan akan berhenti pada usia 18-21 tahun. (3). Pada umumnya, pertambahan tinggi badan remaja berhenti pada jenjang Sekolah Menengah Atas (SMA) atau setingkat. Rata-rata usia siswa SMA adalah 16-18 tahun.

Data Riskesdas tahun 2018 (4) menunjukkan 25,7\% remaja usia 13-15 tahun dan 26,9\% remaja usia $16-18$ tahun berstatus gizi pendek dan sangat pendek. Pertambahan tinggi badan remaja sangat dipengaruhi oleh jumlah sekresi dari Growth Hormone (GH) yang aktif pada masa pubertas dan lebih banyak dikeluarkan sehingga dapat memacu pertumbuhan badan atau mempengaruhi pacu tumbuh pada remaja. (1). Jumlah $\mathrm{GH}$ yang disekresi dapat dipengaruhi oleh beberapa hal, salah satunya adalah jumlah hormon tiroid yang dihasilkan oleh kelenjar tiroid. (5)

Asupan yodium yang kurang dapat menimbulkan berbagai gejala termasuk gondok atau pembesaran kelenjar tiroid. Kelainan ini disebut juga Gangguan Akibat Kekurangan Yodium (GAKY) (6). Yodium merupakan mikronutrien yang berfungsi untuk pembentukan hormon tiroid. Kekurangan yodium dapat menyebabkan hipotiroidisme, penghambatan penyerapan kalsium, gangguan metabolisme karbohidrat dan protein, yang dapat menghambat pertumbuhan (7).

Kekurangan hormon tiroid dapat mengakibatkan pertumbuhan yang berhenti, usia tulang yang terhambat dan postur tubuh pendek. Dari hasil penelitian, remaja dengan kekurangan hormon tiroid atau hipotiroid dapat mengalami kekerdilan.(3)

Gangguan Akibat Kekurangan Yodium (GAKY) merupakan salah satu masalah kesehatan di Indonesia yang berdampak serius kepada masyarakat meliputi kelangsungan hidup dan kualitas sumber daya manusia.(8)

Berdasarkan WHO tahun 2007 diperkirakan 35 juta penduduk di Indonesia kekurangan asupan yodium dan tercatat terdapat 334 kecamatan endemis berat dengan
Total Goitre Rate (TGR) >30\%, 278 kecamatan endemis sedang dengan TGR 20-29,9\%, dan 1.167 kecamatan endemis ringan dengan TGR 5-19,9\%. (8).

Kekurangan yodium umumnya terutama terjadi pada lingkungan miskin yodium. Lingkungan ini disebabkan oleh kurangnya lapisan humus tanah akibat erosi maupun pembakaran hutan yaitu pada daerah pegunungan. (9,10). Di Jawa Tengah terdapat daerah endemis sedang gondok, seperti di Kecamatan Ngargoyoso, Karanganyar, Jawa Tengah dengan TGR $29 \%$. (8)

Menurut Zimmermann (11), bahwa anak yang berada di daerah endemis gondok sejak kecil dan dalam waktu yang lama mempunyai pertumbuhan tinggi badan yang terlambat atau lebih pendek dari anak yang berada di daerah non-endemis gondok.

Berdasarkan penelitian sebelumnya, terdapat perbedaan tinggi badan antara siswa sekolah menengah pertama di daerah endemis gondok dan siswa di daerah non endemis. Namun belum ditemukan penelitian yang meneliti perbedaan tinggi badan pada masa pertumbuhan remaja akhir di daerah endemis dan non endemis penyakit gondok khususnya pada siswa SMK kelas XII di Kabupaten Karanganyar.

\section{METODE}

Penelitian ini dilakukan di SMK Negeri Ngargoyoso yang berada di daerah endemis gondok dan SMK Bina Dhirgantara Colomadu yang berada di daerah non-endemis gondok. Penelitian ini merupakan penelitian observasional analitik dengan menggunakan teknik pengambilan sampling yaitu simple random sampling. Jumlah populasi siswa kelas XII SMK Negeri Ngargoyoso adalah 105 siswa dan sampel yang diambil dalam penelitian ini setelah dihitung dengan menggunakan rumus Slovin didapatkan 84 orang. Sedangkan jumlah siswa kelas XII SMK Bina Dirgantara adalah 154 dan diambil 112 siswa.

Variabel terikat dalam penelitian ini adalah tinggi badan siswa SMK kelas XII. Pengukuran tinggi badan dilakukan dengan menggunakan microtoise. Responden diminta berddiri tegak tanpa menggunakan alas kaki, posisi kepala dan leher tegak serta pandangan lurus kedepan. Pengukuran dilakukan tiga kali kemudian diambil rata-ratanya.

Variabel bebas adalah kondisi prevalensi penyakit gondok di daerah tempat siswa bersekolah, dibedakan menjadi dua kelompok yaitu daerah endemis dan nonendemis gondok. Setelah diperoleh data tinggi badan akan dilakukan analisis data menggunakan uji statistik Tindependent test. 


\section{HASIL DAN PEMBAHASAN}

Penelitian telah dilaksanakan dengan jumlah sampel sebesar 187 orang mendapatkan jumlah siswa laki-laki sebanyak 68 orang $(80,95 \%)$ dan siswa perempuan sebanyak 16 orang $(19,04 \%)$ pada daerah endemis gondok. Sedangkan, pada daerah non-endemis gondok jumlah siswa laki-laki sebanyak 79 orang $(76,69 \%)$ dan jumlah siswa perempuan sebanyak 24 orang $(23,30 \%)$. Perbedaan jumlah sampel pada penelitian ini dikarenakan jumlah populasi pada masing-masing tempat penelitian berbeda. Jumlah populasi pada daerah endemis gondok sejumlah 105 siswa, sedangkan pada daerah non-endemis gondok sejumlah 154 siswa.

Adapun usia siswa yang berada di daerah endemis gondok rata-rata berusia 17,59 tahun dan di daerah nonendemis gondok rata-rata berusia 17,58 tahun.

Tabel 1. Distribusi Variabel Tinggi Badan

\begin{tabular}{ccccc}
\hline $\begin{array}{c}\text { Tinggi } \\
\text { Badan }\end{array}$ & $\begin{array}{c}\text { Daerah Endemis } \\
\text { Gondok }\end{array}$ & \multicolumn{2}{c}{$\begin{array}{c}\text { Daerah Non- } \\
\text { Endemis Gondok }\end{array}$} \\
& $\mathrm{N}$ & $\%$ & $\mathrm{~N}$ & $\%$ \\
\hline $140-150 \mathrm{~cm}$ & 3 & 3,57 & 0 & 0 \\
$150-160 \mathrm{~cm}$ & 28 & 33,33 & 15 & 14.56 \\
$160-170 \mathrm{~cm}$ & 45 & 53,57 & 56 & 54,37 \\
$170-180 \mathrm{~cm}$ & 8 & 9,53 & 30 & 29,13 \\
$>180 \mathrm{~cm}$ & 0 & 0 & 2 & 1,94 \\
& & & & \\
Jumlah & 84 & 100 & 103 & 100 \\
\hline
\end{tabular}

Uji normalitas data dengan menggunakan Kolmogorov-Smirnov (KS-Z) pada variable tinggi badan diperoleh nilai p-value sebesar 0.200 yang berarti data berdisribusi normal sehingga pengujian data tinggi badan menggunakan uji t-independent test.

Tabel 2. Uji Komparatif Tinggi Badan pada Daerah Endemis Gondok dan Non-Endemis Gondok

\begin{tabular}{ccccc}
\hline Daerah & $\mathrm{N}$ & Mean & $\begin{array}{c}\text { Std. } \\
\text { Deviation }\end{array}$ & P-value \\
\hline $\begin{array}{c}\text { Endemis } \\
\text { Gondok }\end{array}$ & 84 & 162,29 & 6,462 & \\
$\begin{array}{c}\text { Non- } \\
\text { Endemis } \\
\text { Gondok }\end{array}$ & 103 & 167,01 & 6,784 & 0,000 \\
\hline
\end{tabular}

Tabel 2. pada uji T-independent test variabel tinggi badan diperoleh nilai mean pada kelompok remaja di daerah endemis gondok $(\mathrm{N}=84)$ sebesar 162,29 $\pm 6,462$ dan kelompok remaja daerah non-endemis gondok $(\mathrm{N}=103)$ sebesar $167,01 \pm 6,784$ dengan nilai $\mathrm{p}=0,001$ yang bermakna adanya perbedaan tinggi badan yang signifikan antara remaja di daerah endemis dan nonendemis gondok di Kabupaten Karanganyar.

Hasil peneltian menunjukkan bahwa tinggi badan remaja di daerah endemis gondok lebih rendah dibanding dengan di daerah non-endemis. Status tinggi badan yang rendah pada siswa SMK di daerah endemis gondok dapat terjadi karena gangguan dari kekurangan yodium. Menurut Trisnavati (12), menemukan bahwa siswa sekolah menengah dari daerah endemis gondok memiliki tingkat pertumbuhan yang lebih rendah dibandingkan siswa dari daerah yang bukan endemis.

Gangguan akibat kurang yodium (GAKY) adalah sekumpulan gejala yang timbul akibat kekurangan unsur yodium secara berkelanjutan dalam jangka waktu yang cukup lama. Keadaan GAKY dapat diidentifikasikan dengan adanya gondok/goiter, kretin, tingginya angka kematian bayi dan menurunnya tingkat kecerdasan (IQ). (13)

Yodium adalah zat yang dibutuhkan oleh tubuh manusia untuk menghasilkan hormon tiroid, yang mengatur pertumbuhan dan perkembangan dari janin hingga dewasa. Yodium berfungsi sebagai bagian integral dari hormon tiroksin / triiodotironin (T3) dan tetraiodotironin (T4) yang keduanya secara bersama dapat disebut hormon tiroid. $(13,9)$

Hormon tiroid berperan meningkatkan absorpsi glukosa dari saluran pencernaan dan meningkatkan tangkapan glukosa oleh jaringan lemak dan otot. (9). Hormon T3 itu, dan T4 berfungsi mengatur suhu tubuh, reproduksi, pembentukan sel darah merah serta fungsi otot dan saraf. Selain itu, hormon T3 dan T4 juga menambah meningkatkan Basal Metabolic Rate (BMR), membantu regulasi pertumbuhan tulang panjang, dan maturasi saraf. (14)

Pelepasan hormon tiroid dirangsang oleh suatu hormon yang dikeluarkan oleh hipofisis anterior yaitu Thyroid Stimulating Hormone (TSH). Hormon TSH ini akan dirangsang oleh suatu hormon yang dikeluarkan oleh hipotalamus yaitu Thyroid Releasing Hormon (TRH). (9)

Masalah GAKY merupakan masalah yang sangat serius karena dapat menyerang semua golongan umur mulai dari janin hingga dewasa dan menimbulkan permasalahan yang berbeda sesuai golongan umurnya. (13)

Permasalahan GAKY dapat diakibatkan oleh beberapa faktor:

a. Defisiensi yodium dalam makanan 
Rendahnya yodium dalam makanan dapat dipengaruhi oleh tempat tumbuhnya bahan makanan yang dikonsumsi. Bahan makanan yang tumbuh di daerah yang memiliki tanah kurang yodium maka bahan makanan yang dihasilkan memiliki kandungan yodium yang sedikit. (12)

Hal-hal yang mempengaruhi kondisi tanah tersebut antara lain, kejadian erosi yang menyebabkan kandungan yodium terkikis. Kejadian erosi sering terjadi di daerah pegunungan seperti pada daerah Ngargoyoso. $(12,10)$

b. Zat goitrogenik dalam makanan

Goitrin merupakan senyawa anti tiroid yang terdapat pada bahan makanan seperti kol dan kubis-kubis lainnya. Tingginya zat goitrogenik yang dikonsumsi dapat mempengaruhi dan meningkatkan kejadian GAKY. $(12,13)$

Pada pelaksanaan penelitian ini, terdapat beberapa keterbatasan, seperti tidak diperhatikan daerah asal siswa atau responden, aktivitas fisik responden, dan status ekonomi dan sosial orangtua responden.

\section{KESIMPULAN}

Tinggi badan remaja di daerah endemis gondok di Kecamatan Ngargoyoso Kabupaten Karanganyar lebih rendah dibandingkan remaja di daerah non endemis gondok.

\section{DAFTAR PUSTAKA}

1. Batubara, J. R. (2010). Adolescent Development (Perkembangan Remaja). Sari Pediatri 2010; 12(1): 21-29.

2. Stang, J., \& Story, M. (2005). Guidelines of Adolescent Nutrition Services. Minneapolis: Center for Leadership, Education and Training in Maternal and Child Nutrition, Division of Epidemiology and Community Health, School of Public Health, University of Minnesota.

3. Gutch, M., Philip, R., Philip, R., Toms, A., Saran, S., \& Gupta, K. (2013) Skeletal Manifestations of Juvenile Hypothyroidism and The Impact of Treatment on Skeletal System. Indian J Endocrinol Metab; Vol 17: 181-3.

4. Kesehatan, B. P. Riset Kesehatan Dasar (2018) Jakarta: Departemen Kesehatan RI. 2018

5. Guyton, A. C., \& Hall, J. E. (2007) Buku Ajar Fisiologi Kedokteran Edisi 11. Jakarta: EGC.

6. Djokomoeljanto, R. (2007) Gangguan akibat kekurangan iodium (GAKI) dan Kelebihan Iodium (EKSES). Tiroidologi Klinik. Semarang: Badan Penerbit Universitas Diponegoro.

7. Hetzel, B. (2004) An Overview of the Global Program for the Elimination of Brain Damage Due to Iodine Deficiency. In: Towards the Global Elimination of Brain Damage Due to Iodine Deficiency. New Delhi: Oxford University Press.

8. Dewi, Y. L. (2011) Hubungan Iodium dan Kecerdasan. Seminar Nasional VIII Pendidikan Biologi; Surakarta; p 139-144.

9. Gatie, A. L. (2006) Validasi Total Goitre Rate (TGR) Berdasar Palpasi Terhadap Ultrasonografi (USG) Tiroid serta Kandungan Yodium Garam dan Air di Kecamatan Sirampos Kabupaten Brebes. Semarang: Universitas Diponegoro.

10. Zimmermann, M. B. (2009) Iodine Deficiency. Endocr Rev; 30(04): 376-408.

11. Zimmermann, M.B. (2011) The Role of iodine in human growth and development. Seminars in Cell \& Development Biology 22; p: 645-652. Zurich. 2011

12. Trisnawati, I. G. (2015) Tingkat Pertumbuhan Tinggi Badan dan Status Gizi Siswa SMP di Daerah Endemik dan Non Endemik GAKI di Kabupaten Tabanan. Jurnal Virgin; 1(1): 50-67.

13. Dewi, D. C. (2014) Faktor - Faktor yang Berhubungan dengan Kejadian Gangguan Akibat Kurang Yodium (GAKY) di Daerah Pegunungan Kapur Wonogiri Jawa Tengah. Jurnal Medika Respati; Vol. 9 No. 3.

14. Turianica, I., \& Rothova, M. (2012) Symptoms and Prevention of The Iodine Deficiency. J Microbiol Biotechnol Food Sci; 2 (2): 803-12. 